IRA-International Journal of Management \& Social Sciences

ISSN 2455-2267; Vol.07, Issue 02 (2017)

Pg. no. $270-280$

Institute of Research Advances

http://research-advances.org/index.php/RAJMSS

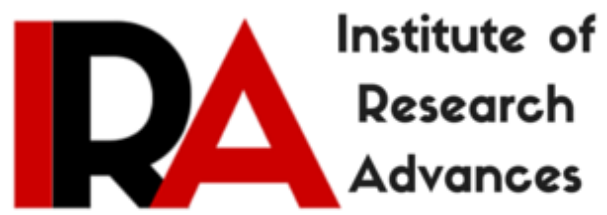

\title{
Study on Factors Influencing Employee Retention among the Employee of Fashion Institutes in Mumbai
}

\author{
Dr. Shalini Wadhwa \\ Assistant Professor, HR Department, Bunts Sangha's UKS Institute of Management \\ Studies and Research, Mumbai, India. \\ Dr. Krishna Shetty \\ Director, Bunts Sangha's UKS Institute of Management Studies and Research, Mumbai, \\ India.
}

Type of Review: Peer Reviewed.

DOI: http://dx.doi.org/10.21013/jmss.v7.n2.p17

\section{How to cite this paper:}

Wadhwa, S., \& Shetty, K. (2017). Study on Factors Influencing Employee Retention among the Employee of Fashion Institutes in Mumbai. IRA-International Journal of Management \& Social Sciences (ISSN 2455-2267), 7(2), 270-280. doi:http://dx.doi.org/10.21013/jmss.v7.n2.p17

(C) Institute of Research Advances

\section{(cc) EY-NC}

This work is licensed under a Creative Commons Attribution-Non Commercial 4.0 International License subject to proper citation to the publication source of the work.

Disclaimer: The scholarly papers as reviewed and published by the Institute of Research Advances (IRA) are the views and opinions of their respective authors and are not the views or opinions of the IRA. The IRA disclaims of any harm or loss caused due to the published content to any party. 


\begin{abstract}
Fashion Designing colleges experienced faculty/staff are always in demand. It becomes difficult for the colleges to retain their experienced staff. This study was conducted to know the impact of the various policies like Training and Appraisal Policy, Reward policy etc. on employees' retention. Specific objectives of the study cover the measurement of employee's satisfaction with respect to the Training and Appraisal systems prevalent in the organization and how it impacts retention of employees.

The study population was from various fashion institutes of Mumbai.

The study reveals that the staff performance is greatly affected by the Training and Appraisal system, Reward system and career growth opportunities in the Fashion designing colleges. Researcher recommends improving all these policies in order to increase the overall satisfaction of employees which in turn will lead to increased employee retention.
\end{abstract}

KEYWORDS: Fashion designing, Retention policy, retention of employees, factors affecting retention.

\title{
I. INTRODUCTION
}

\section{$1.1 \quad$ Objectives}

1. To identify the various retention policies prevalent in fashion Institutes of Mumbai.

2. To understand the level of satisfaction of employees with respect to salary structure, benefits, disciplinary procedures, career growth and performance appraisal policies of fashion institutes.

3. To know the impact of retention techniques on retention of employees in fashion Institutes of Mumbai.

\subsection{Research Methodology}

Significance of the Study

This study would bring to light employees satisfaction with respect to retention policies and the extent to which this impacts their retention in the organization. Also, it would contribute to the knowledge \& literature because it would focus on which retention policy needs a review in order to improve the retention in the organization.

Further, it would provide information for human resource practitioner on how rules and regulation regarding HRM policies work in B.D. Somani and International institute fashion designing College and develop the necessary program to develop the necessary program to address weaknesses \& improve Employee Retention.

\subsection{Sample size}

The sample for the study was collected from the senior and junior faculties and staff from the various departments of the fashion designing Colleges of Mumbai located at Thane (W) and Churchgate. The researcher limited the sample size to seventy-five(75).

\subsection{Sampling Method}

Convenience sampling technique was adopted in the selection of the sample units or respondents from the departments.

\subsection{Data Collection}

Primary and secondary sources of data were used in the research.

1.6 Primary Source

Questionnaire consisting 35 questions was used in the collection of the primary data. Interviews were also taken wherever found necessary. 


\subsection{Secondary Source}

Secondary data was collected through the use of books, articles, journals, and handouts on human resource development. Electronic search engines such as the internet and Encyclopaedia were also used.

\subsection{Limitations of the Study}

The research finds that the time span with in which to complete this work may not be enough to allow for a comprehensive study of the research area. Due to lack of time and my inability to understand the fashion college in full swing I had some limitations as I am not from the same background but have tried to put in my hundred percent.

\subsection{Literature review}

During the course of our research several HR practices have been found to help employee retention and enhance employee commitment in an organisation which is discussed in the following work.

\section{Career development opportunities}

One of the reasons for high employee turnover in organizations is that the organizations don't plan a career path for employees. I $t$ is very essential to plan the career of employees the moment they enter the organization. (Hay 2001). They should be given opportunities to build their skill set so that they can prepare themselves for future positions and look at long-term career prospects instead of shortterm employment (Gaurav Bagga 2013).

\section{Effective talent management strategies}

Employees look for jobs which challenge them and are so designed to tap their potential to the fullest. Therefore, those employers which have talent management practices in place succeed in creating a positive brand image of the organization where employees want to work. (Julia Christensen Hughes and Evelyn Rog 2008).

\section{Recruitment}

Recruitment of right person in the organization is very important. A person who is not only fit for the job but for the organization as whole should be taken in, keeping in mind the person-culture fit. If a person doesn't share the values of the organization, he/she may not stick to the organization for long especially when there is so much of unemployment (Simon North, 2011).

\section{Training \& Development}

Generally, there is debate on whether employees should be given training or notas there is a possibility that they may leave the organization after getting training. However, it has been observed that trained employees are loyal and committed to the organization (Sarah Leidner, 2013). Therefore, organizations investing in training and development are always observed to have better employee retention.

\section{Compensation and Benefits}

Compensation and benefits given to the employees should be little higher than the industry standards so that employees can be retained in the organization. Care should be taken and in order to retain employees in the organization, they should not be paid more than required as it will affect the compensation of all the employees in the organization. (David Pollitt 2007).

\section{Work Life Balance}

Flexible work hours, work from home facility, proper working conditions, elder care, child care facilities etc. help employees to maintain a balance in their work and life which improves their satisfaction level and helps in reducing turnover (Osman M. Karatepe 2013). 


\subsection{Introduction to employee retention factors}

We are in knowledge era. In this era, human resources have gained paramount importance as they are the carriers of the knowledge. Organizations can't afford to consider human beings as a passive resource. Human resources are known as human capital and are considered very critical. Human resources are the only resource in this knowledge economy which can give one organization a competitive edge over other organization. Knowledge workers are in demand in every industry. Companies adopt various strategies to attract and poach skilled and knowledgeable workers as such workers always bring the knowledge which gives competitive advantage to these organizations.

This has made organizations to think about various retention policies as it has become very difficult to retain employees in this era. Most of the organizations are affected by high turnover ratios. High attrition is very costly affair for the companies. It results in wastage of time, money, efforts and the training which is imparted to the employees when they join the company. Therefore, several organizations have carved out unique and interesting retention policies to retain their employees. It is a challenge for the companies to match employee aspirations with organization goals. Some of the retention policies include.

Performance Appraisal: Performance appraisals are replaced with Performance management. It is a continuous process unlike Performance appraisal. Some organizations have started appraising performance on real-time basis. It has become more open and transparent. Employees are involved in the process of appraisal and are also given an opportunity to raise their concerns if any

\section{Rewards and Recognition}

Employees want to be respected, recognized and rewarded. Rewards are linked with the performance. Employees like to be associated with organization where they and their efforts are valued. Reward policies are designed in such way that these fulfil individual requirements and organization goals.

\section{Career Management}

Employees should look at the organizations as a long term employment and not as short-time affair. Therefore, organizations chalk out career paths for the employees as soon as they join the organization. A well laid out career plan gives employees encouragement and motivates them to stay in the organization for a longer period of time.

\section{Recruitment}

Recently, there is an orientation to find a person organization fit than person-job fit. A person who is fit for the organization is inducted. Organizations scan prospective employee's social media posts and also make reference checks to know if he/ she are the right match for the organization as a whole. Organizations try to discern if the person shares the values of the organization or not and if he will be able to adapt to the culture of the organization.

\section{DATA ANALYSIS AND INTERPRETATION}

\section{Hypothesis Testing}

Null Hypothesis: There is no association between Satisfaction level w.r.t. training and development and Level of employee Retention.

Alternate Hypothesis: There is association between Satisfaction level w.r.t. training and development and Level of employee Retention.

To test above hypothesis Chi-square test is applied result of test is as follow 


\section{Level of Satisfaction Training Development * Level of Employee Retention}

Crosstab

Count

\begin{tabular}{|ll|r|r|r|r|}
\hline & & \multicolumn{2}{|c|}{ Level_of_Employee_Retention } & \multirow{2}{*}{ Total } \\
\cline { 3 - 5 } & & \multicolumn{1}{|c|}{ High } & Low & Medium & \\
\hline \multirow{2}{*}{ Level_of_Satisfaction_Train } & High & 0 & 0 & 13 & 13 \\
ing_Development & Low & 0 & 6 & 3 & 9 \\
\multirow{2}{*}{ Total } & Medium & 7 & 10 & 36 & 53 \\
\hline
\end{tabular}

Chi-Square Tests

\begin{tabular}{|l|r|r|r|}
\hline & Value & df & $\begin{array}{c}\text { Asymp. Sig. (2- } \\
\text { sided) }\end{array}$ \\
\hline Pearson Chi-Square & $17.961^{\mathrm{a}}$ & 4 & .001 \\
Likelihood Ratio & 19.728 & & .001 \\
N of Valid Cases & 75 & & \\
\hline
\end{tabular}

a. 5 cells $(55.6 \%)$ have expected count less than 5 . The minimum expected count is .84 .

Above table indicates that $p$-value of chi-square test is 0.001 which is lesser than standard table value 0.05 therefore test is selected.

Hence, null hypothesis rejected and alternate hypothesis is selected

Conclusion is there is association between Satisfaction Level of Training and Development and Level of Retention

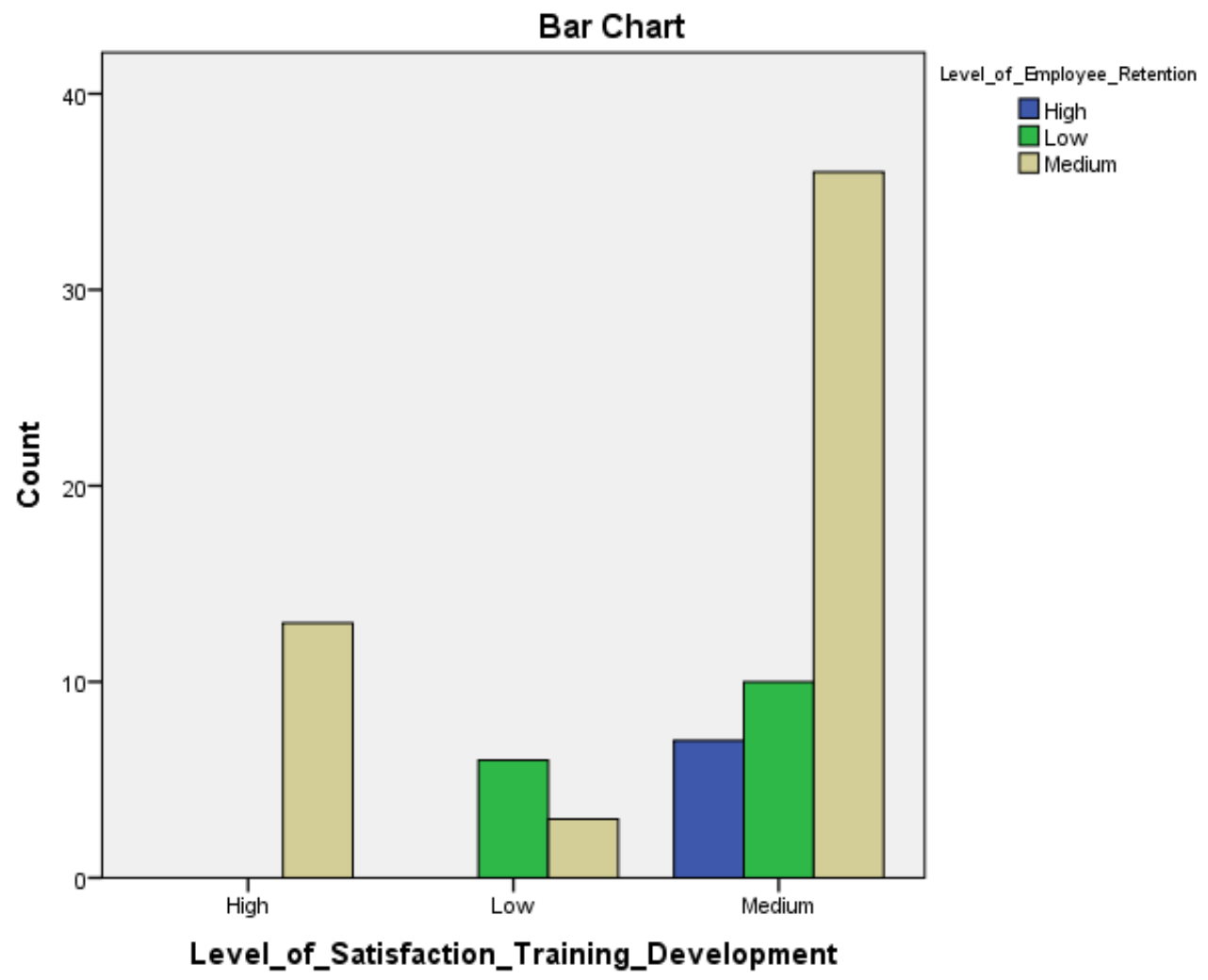


Null Hypothesis: There is no association between Satisfaction level w.r.t Performance Appraisal and Level of employee Retention.

Alternate Hypothesis: There is association between Satisfaction level w.r.t. Performance Appraisal and development and Level of employee Retention.

\section{Level of Satisfaction Performance Appraisal * Level of Employee Retention}

\begin{tabular}{|c|c|c|c|c|c|}
\hline & & $\begin{array}{l}\text { osstab } \\
\text { ount }\end{array}$ & & & \\
\hline & & Level & nploy & etention & Total \\
\hline & & High & Low & Medium & \\
\hline & High & 7 & 0 & 0 & 7 \\
\hline Level_of_Satisfaction_Perfo & Low & 0 & 6 & 4 & 10 \\
\hline & Medium & 0 & 10 & 48 & 58 \\
\hline Total & & 7 & 16 & 52 & 75 \\
\hline
\end{tabular}

Chi-Square Tests

\begin{tabular}{|l|r|r|r|}
\hline & \multicolumn{1}{|c|}{ Value } & df & $\begin{array}{c}\text { Asymp. Sig. (2- } \\
\text { sided) }\end{array}$ \\
\hline Pearson Chi-Square & $84.559^{\mathrm{a}}$ & 4 & .000 \\
Likelihood Ratio & 53.944 & & .000 \\
N of Valid Cases & 75 & & \\
\hline
\end{tabular}

a. 5 cells $(55.6 \%)$ have expected count less than 5 . The minimum expected count is .65 .

Above table indicates that p-value of chi-square test is 0.000 which is lesser than standard table value 0.05 therefore test is selected.

Hence, null hypothesis rejected and alternate hypothesis is selected

Conclusion is there is association between Satisfaction Level of Performance Appraisal and Level of Retention

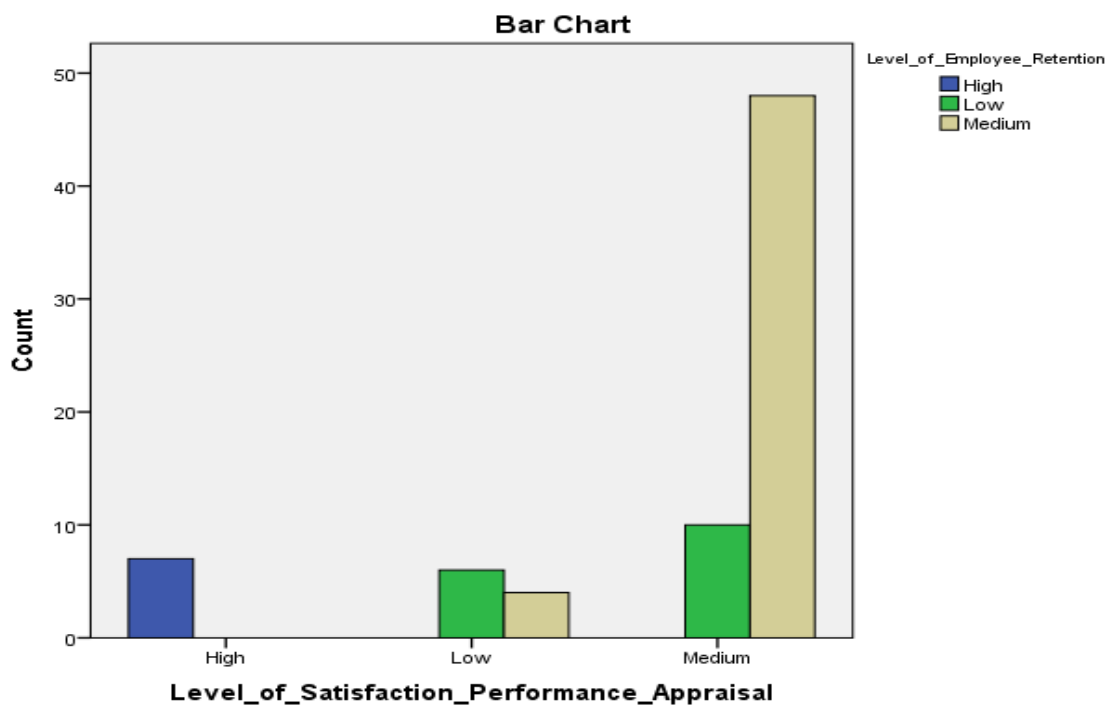


Null Hypothesis: There is no association between Satisfaction level w.r.t Career growth and Level of employee Retention.

Alternate Hypothesis: There is association between Satisfaction level w.r.t. Career growth and Level of employee Retention.

\section{Level of Satisfaction Career Growth* Level of Employee Retention}

\section{Crosstab}

Count

\begin{tabular}{|ll|r|r|r|r|}
\hline \multirow{2}{*}{} & & \multicolumn{2}{|c|}{ Level_of_Employee_Retention } & \multirow{2}{*}{ Total } \\
\cline { 2 - 4 } & \multicolumn{1}{|r|}{ High } & Low & Medium & \\
\hline \multirow{2}{*}{ Level_of_Satisfaction_Caree } & High & 7 & 0 & 3 & 10 \\
r_Growth & Low & 0 & 5 & 16 & 21 \\
& Medium & 0 & 11 & 33 & 44 \\
Total & & 7 & 16 & 52 & 75 \\
\hline
\end{tabular}

Chi-Square Tests

\begin{tabular}{|l|r|r|r|}
\hline & \multicolumn{1}{|c|}{ Value } & \multicolumn{1}{|c|}{ df } & $\begin{array}{c}\text { Asymp. Sig. (2- } \\
\text { sided) }\end{array}$ \\
\hline Pearson Chi-Square & $50.549^{\mathrm{a}}$ & 4 & .000 \\
Likelihood Ratio & 35.973 & & .000 \\
N of Valid Cases & 75 & & \\
\hline
\end{tabular}

a. 5 cells $(55.6 \%)$ have expected count less than 5 . The minimum expected count is .93 .

Above table indicates that $\mathrm{p}$-value of chi-square test is 0.000 which is lesser than standard table value 0.05 therefore test is selected.

Hence, null hypothesis rejected and alternate hypothesis is selected

\section{Conclusion is there is association between Satisfaction Level of Career growth and Level of Retention}

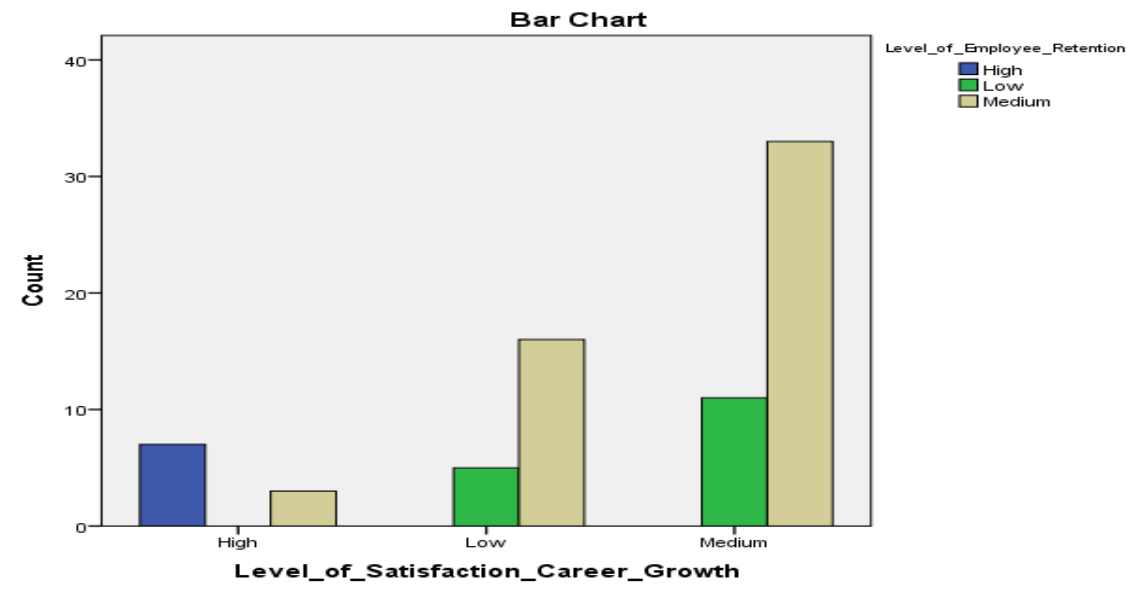

Null Hypothesis: There is no association between Age of respondents and Level of satisfaction w.r.t. reward policy. 
Alternate Hypothesis: There is association between Age of respondents and Level of satisfaction w.r.t. reward policy.

\section{Level of Satisfaction Rewards * Age}

Count

\section{Crosstab}

\begin{tabular}{|c|c|c|c|c|c|}
\hline & \multicolumn{3}{|c|}{ Age } & \multirow[t]{2}{*}{ Total } \\
\hline & & Middle & Old & Young & \\
\hline \multirow{4}{*}{$\begin{array}{l}\text { Level_of_Satisfaction_Rewa } \\
\text { rds } \\
\text { Total }\end{array}$} & High & 0 & 2 & 0 & 2 \\
\hline & Low & 5 & 0 & 9 & 14 \\
\hline & Medium & 24 & 0 & 35 & 59 \\
\hline & & 29 & 2 & 44 & 75 \\
\hline
\end{tabular}

Chi-Square Tests

\begin{tabular}{|l|r|r|r|}
\hline & \multicolumn{1}{|c|}{ Value } & df & $\begin{array}{c}\text { Asymp. Sig. (2- } \\
\text { sided) }\end{array}$ \\
\hline Pearson Chi-Square & $75.120^{\mathrm{a}}$ & 4 & .000 \\
Likelihood Ratio & 18.561 & & .001 \\
N of Valid Cases & 75 & & \\
\hline
\end{tabular}

a. 5 cells $(55.6 \%)$ have expected count less than 5 . The minimum expected count is .05 .

Above table indicates that $\mathrm{p}$-value of chi-square test is 0.000 which is lesser than standard table value 0.05 therefore test is selected.

Hence, null hypothesis rejected and alternate hypothesis is selected

\section{Conclusion is there is association between Satisfaction Level of Rewards and Age of respondents.}

Null Hypothesis: There is no association between Designation of respondents and Level of satisfaction w.r.t. reward policy.

Alternate Hypothesis: There is association between Designation of respondents and Level of satisfaction w.r.t. reward policy.

\section{Designation * Level of Satisfaction Rewards}

\section{Crosstab}

Count

\begin{tabular}{|c|c|c|c|c|c|}
\hline & \multicolumn{3}{|c|}{ Level_of_Satisfaction_Rewards } & \multirow[t]{2}{*}{ Total } \\
\hline & & High & Low & Medium & \\
\hline \multirow{9}{*}{ Designation } & ADMIN STAFF & 0 & 1 & 1 & 2 \\
\hline & CO-ORDINATOR & 0 & 0 & 1 & 1 \\
\hline & COSTUME DESIGNER & 1 & 0 & 0 & 1 \\
\hline & FABRIC DISTRIBUTOR & 0 & 1 & 0 & 1 \\
\hline & FACULTY DRAFTING & 0 & 0 & 2 & 2 \\
\hline & FACULTY FD & 0 & 7 & 26 & 33 \\
\hline & FACULTY ID & 0 & 1 & 18 & 19 \\
\hline & FACULTY MER & 0 & 0 & 2 & 2 \\
\hline & FACULTY TD & 0 & 0 & 2 & 2 \\
\hline
\end{tabular}




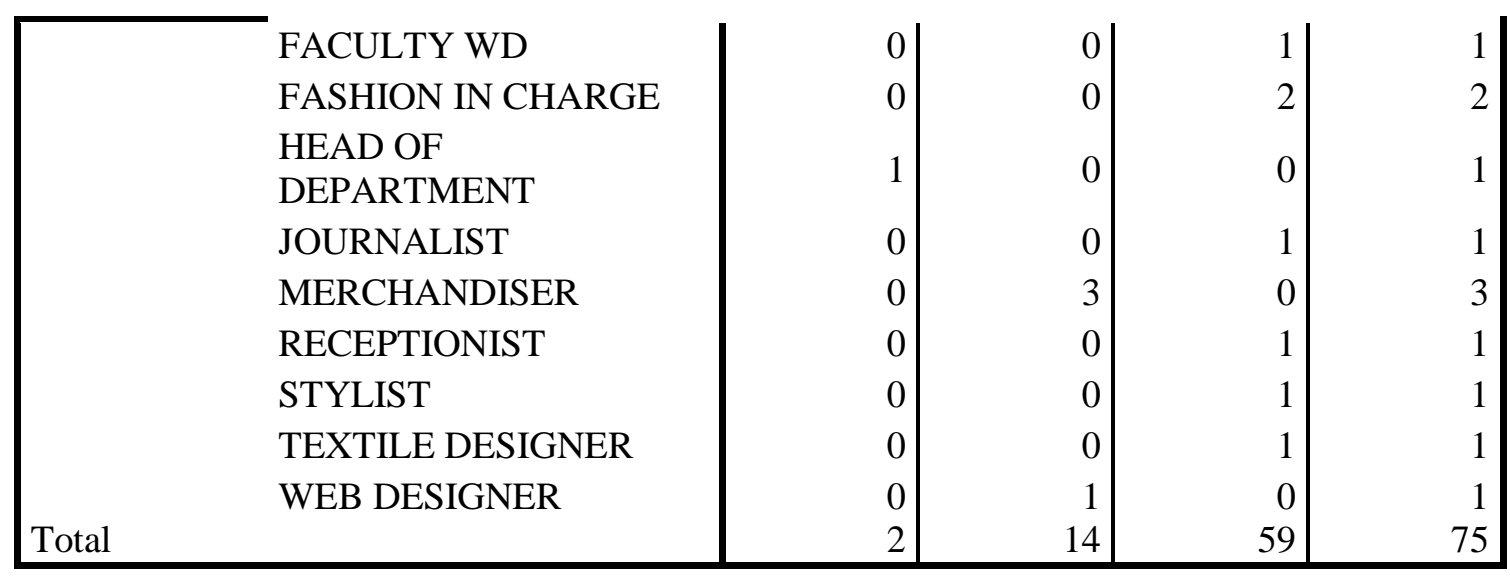

Chi-Square Tests

\begin{tabular}{|l|r|r|r|}
\hline & \multicolumn{1}{|c|}{ Value } & df & $\begin{array}{c}\text { Asymp. Sig. (2- } \\
\text { sided) }\end{array}$ \\
\hline Pearson Chi-Square & $103.850^{\mathrm{a}}$ & 34 & .000 \\
Likelihood Ratio & 45.094 & 34 & .097 \\
N of Valid Cases & 75 & & \\
\hline
\end{tabular}

a. 51 cells $(94.4 \%)$ have expected count less than 5 . The minimum

expected count is .03 .

Above table indicates that p-value of chi-square test is 0.000 which is lesser than standard table value 0.05 therefore test is selected.

Hence, null hypothesis rejected and alternate hypothesis is selected

Conclusion is there is association between Satisfaction Level w.r.t. Rewards policy and Designation of respondents.

\section{SUMMARY OF FINDINGS, CONCLUSIONS AND RECOMMENDATIONS}

Major findings of the present study are mentioned below:

\section{Training\& Development Process}

It is evident from the data that there is an association between training and development policies of the organization and level of perceived retention of the employees. The more the employees satisfied with the training and development opportunities (13\% -highly satisfied) available in the organization the more they are likely to stay in the organization.

\section{Performance Appraisal}

Data makes it clear that $13 \%$ employees are not satisfied with the performance appraisal system prevalent in the fashion institutes. It is proven that there is relation between satisfaction level of the employees' w.r.t. performance appraisal policies and level of retention in the organization.

\section{Reward System}

About $18 \%$ of the employees are not satisfied with the reward policies of the organization. 59\% respondents have medium level of satisfaction with reward policies. $20 \%$ of the young employees have low satisfaction level w.r.t. reward policies. About $20 \%$ of faculty belonging to Fashion Designing department are observed to have low satisfaction with respect to reward policies prevalent 
in the colleges. Therefore, it can be determined that not many employees are happy with the reward system followed in the colleges.

\section{Career Growth}

$28 \%$ of the employees are not satisfied with the career growth opportunities in the organization and it is proven that there is association between satisfaction w.r.t. career growth and retention level of employees.

\section{Welfare Benefits}

$29 \%$ of the respondents are not happy with the welfare benefits provided by the colleges.

\section{Recommendations}

From the study it is realized that Training, Appraisal and Reward policies play important role in retaining employees in the organization. These recommendations are therefore made to help make these practices more effective.

\section{Training and Development}

It was observed by the researcher that employees are enthusiastic about the training programs conducted by the colleges. But it was felt that in order to bring in the behavioural changes in the employees reinforcement is essential. Therefore, regular training programs are demand of the day.

It is also recommended that refresher courses should be organised for the employees to make them abreast with trends in the ever growing market.

\section{Performance Appraisal}

It is evident from the findings significant number of employees consider performance appraisal as a partial process. The human resource department should particularly work towards it. Objectives systems of appraisal like 360 degree appraisal system can be introduced to bring in transparency. It will also give a holistic view of employee's performance which will in turn help the HR department in formulating training and development policies, in performing job analysis and also in deciding the salary raise of the employee in objective manner. If resources are available company can also adopt Behaviourally Anchored Rating Scale (BARS) for appraising the employees. It will help in judging employees behaviour in critical situation effectively and objectively.

\section{Reward System}

It is observed during the study that young employees are not that satisfied with the reward system of the colleges. Therefore, the management should adopt a system where the work of young employees can be recognized. A portal can be launched where the work done by the staff can be displayed, shared and appreciated. This will not only reinforce such kind of behaviour but will also motivate them tremendously.

\section{Career Growth}

Colleges should have well laid out career path for the employees. Regular promotions, rotation of jobs to broaden their knowledge and opportunities to enhance skills so that they get prepared for leadership positions are very essential. This is an important factor in retaining employees.

\section{Conclusion}

The study has examined the effects of training and development, career growth, reward system and performance appraisal policies on the performance of employees in fashion institutes of Mumbai. Several critical observations have been made from findings to the study. It is important to point out that one of the responsibilities of management is to ensure that an organization functions effectively and efficiently. In order to achieve these goals, management must be able to provide quality pool of employees to the organisation, determine and assess performance levels of both the organization and its individual employees and plan effective training and development programs. 
Organisations depend upon the quality of human resources working in the organisations. Once the employees are inducted in the organisation, measurement of employee's performance level is also a key process in order to achieve company's objective. On the basis of appraisal of the employee's training programs are developed to enhance the competencies of the employees wherever required. Employees also need to be developed for future jobs in the organisation and managers need to prepare the high performers for key positions in the organisation. In short, all these factors or parameters have profound impact on the performance of the employees in the organisation.

So, HR managers and top level executives should strive to make these processes more transparent, objective, relevant and effective through various possible means and ways.

\section{References}

1. Bhatnagar, J.," Talent management strategy of employee engagement in Indian ITES employees: key to retention" Employee Relations Vol. 29 No. 6, 2007 pp. 640-663 2.

2. Cottrell, T.," Returns and investments "Retreat. Reveal. Retain" The Bottom Line: Managing library finances Vol. 25 No. 4, 2012 pp. 155-158,2012 3.

3. Michael Hay," Strategies for survival in war of talent": Career development International 7/1 (2002).

4. Margaret Deery," Talent management, work-life balance and retention strategies: International Journal of Contemporary Hospitality Management Vol. 20 No. 7, 2008 pp. 792-806 5.

5. V. Rama Devi, "Employee engagement is a two way street": Human Resource management International digest Vol. 17 NO. 2 2009, pp. 3-4 6.

6. Piyali Ghosh and Rachita Satyawadi," Who stays with you? Factors predicting employees' intention to stay": International Journal of Organizational Analysis Vol. 21 No. 3, 2013 pp. 288-312. 